\title{
A Thematic Analyses of the Researches Conducted in the Alternative Learning System (ALS) Across Programs
}

\author{
Rufo A. Labarrete
}

\section{ABSTRACT}

Researches in the ALS vary in scope and themes. This academic undertaking examines published researches in ALS to determine common themes and identify implications on the implementations of its various programs. Thematic analysis is utilized in identifying the patterns of such researches as they were coded based on key words. Findings reveal that studies involving the ALS were focused on programs impact to the learners, development of instructional resources, and on concerns pertinent to teaching and learning. Thus, it can be concluded that there is enough empirical-based data that may serve as bases by the policy makers in the ALS to further improve the implementation of its various programs in the field and set direction on research engagement in this learning system.

Keywords: Alternative Learning System, ALS Programs, IlliteracyPolicy Direction, Thematic Analyses, Research Direction in the ALS.

\author{
Published Online: June 20, 2021 \\ ISSN: $2736-4534$ \\ DOI :10.24018/ejedu.2021.2.3.46 \\ Rufo A. Labarrete*, PhD \\ Leyte Normal University, Tacloban City, \\ Leyte, The Philippines. \\ (e-mail: labarrete@yahoo.com)
}

*Corresponding Author

\section{INTRODUCTION}

Creating an illiterate-free global village is one of the core mandates of the United Nations Educational Scientific Cultural Organization (UNESCO). Given this, a number of programs for education intended for this purpose were launched. Education For All (EFA), Millennium Development Goals (MDGs) and the current Sustainable Development Goals (SGDs) are among these programs rolled out by the agency.

In spite of the gargantuan efforts of the agency to combat illiteracy, however, the UNESCO Institute for Statistics (UIS) reported that as of 2018, 258.4 million children, adolescents and youth are still out of school. These numbers represent one-sixth of the world's population of this age group. These figures, the UIS claimed, suggest that the world is still far from attaining its goal for the universal access to primary and secondary education.

As reported by the United Nations Human Development Report in 2016, the Philippines is one of the Southeast Asian nations with high literacy rate which stood at $98.9 \%$ and $97 \%$ among men and women aged 15-24 respectively. While high, the Philippine Statistics Authority reported that the two percent gap represents 3.6 million youth aged 16-24 who are out of school premises as of 2017. This number though is much lower than the registered 3.8 million in 2016 [1].

The country's sterling performance in addressing illiteracy both international and domestic can be credited to the government's effort to combat this menace. More than a decade ago, the government has committed to uphold UNESCO-led programs such as the EFA, MGDs, and the most recent SDGs. This commitment is further bolstered by legislating Republic Act 9155 or the Governance of Basic Education Act of 2001. This law served as the legal framework for a major reform of the country's basic education system. Among others, it guaranteed the delivery of education through an alternative viable mode. Thus, the birth of the country's Alternative Learning System (ALS) Thereafter, Executive Order No. 365, s. 2004 was issued that created the Bureau of Alternative Learning System (BALS) of the Department of Education (DepEd). BALS would then become the lead bureau for the implementation of all program offerings in the ALS. ALS is defined in RA 9155 as a parallel learning system to provide a viable alternative to the existing formal education instruction. It encompasses both the nonformal and informal sources of knowledge and skills. Its program offerings are clientele-needs-based. These include Basic Literacy Program (BLP), Accreditation and Equivalency (A\&E), Indigenous Peoples Education (IPEd), Arabic Language and Islamic Values Education in ALS (ALIVE in ALS), ALS for Differently-Abled Persons (ALSDAP), Radio-Based Instruction (RBI) and Education and Skills Training (EST) among others [2].

Years after various ALS programs have been institutionalized, a number of studies across country were conducted and had since been published. However, there is no single study that is focused on thematically analyzing the 
direction of the existing studies conducted involving the ALS in general. With this in mind, this present academic undertaking then intends to thematize studies conducted in the ALS from the year 2010 onwards with the end goal of determining which areas have been explored and unexplored for empirical investigations. The results of this undertaking may be used as a baseline data helpful in creating policy direction for research in the ALS.

\section{METHODS}

This paper utilized the descriptive qualitative research method which examines the scope and themes of selected published researches in the ALS. Using Braun and Clarke (2006) six-phase framework in doing thematic analysis, 19 published researches in the ALS across programs that were accessed from refereed and indexed education journals, were analyzed, coded and clustered based on constructs and themes. Semantic and latent themes were given due consideration in the interpretation and analysis of the studies selected. Thereafter, themes were generated on the bases of the underlying ideas, assumptions, and conceptualization of the published studies.

\section{RESULTS}

\section{A. Theme One: Positive Impact of the Program, Delivery to the Lives of the Enrollees}

Several studies have been conducted involving the learners of the A\&E program. Findings of these academic endeavors reported the positive impact of the program delivery to the lives of the enrollees. Apao, Dayagbil, and Abao [3] for example, reported that well-implemented ALS-A\&E programs in Cebu province paved the way for the attainment of life skills and a high literacy rate of the learners which, in turn, led to the employment of program completers and high turnout of successful examinees in the A\&E Test. Dayon, Garcines, and Sael [4] on the other hand, credited the ALS the literacy program as being instrumental in augmenting the socio-economic standing of the Badjaos for they have become more employable after having completed the skills training provided to them. Similarly, Flores [5] claimed that young mothers in Cebu enrolled in this program considered it as their stepping stone to obtain a high school diploma and eventually land into a decent job. Furthermore, Enriquez [6] traced the benefits gained by the A\&E completers of the four districts in the Division of Lucena City and reported that the graduates positively gained from their attendance and completion of the program as majority of them got employed while a considerable proportion had pursued a degree in college. These advancements, he said, were attributed by the completers to the dynamic curriculum and instructional modalities employed by the programs implementers in the locality.

Meanwhile, Moralista and Delariarte [7] averred that the ALS education is indeed very helpful in cultivating the cognitive abilities of a group of IPs thriving in Barangay Matag-ob, Janiuay, Iloilo specifically in learning subjects including Kabuhayan at Likas na Yaman, Kasayanay Pangkomunikasyon, Matematik at Agham, and
Pagpapalawak ng Pananaw. Finally, Labarrete [8] reported that the Alternative Learning System - Education and Skills Training (ALS-EST) program is effectively implemented as evaluated by the learners in an ALS Center in a town in Leyte Province. The academic preparations, he said, are pivot to character formation, employment-related skills training, and academic skills. The program is well-received and is viewed by its learners as an academic ladder and as a catalyst to a better life.

\section{B. Theme Two: On Instructional Resources Developed}

The Melgar [9], [10] twins both developed an Online DepEd-based ALS Programs for the A\&E learners in Cebu City. These programs were focused on the six Learning Strands of the new ALS K to 12 Curriculum. The first program concentrated on Scientific and Critical Thinking Skills, Mathematics and Problem Solving Skills, and Digital Literacy while the other was focused on Communication Skills, Life and Career Skills, and Understanding Self and Society. Reports of the findings of their studies said that learners and learning facilitators rated both programs as technically well-done, user friendly, practical, and responsive to the learners' needs. It was thus recommended that these be utilized by the programs implementers in facilitating these Learning Strands. Labarrete [11] on the other hand, proposed two modules for the course Modalities and Assessment of Learning in Post-Baccalaureate Diploma in Alternative Learning System (PB-DALS). Both modules were designed on the 4As strategy on teaching as suggested in Kolb's Experiential Learning Theory which includes Activity, Analysis, Abstraction; and Application. The modules' contents were anchored on the results of the findings reported as regards modalities and assessments of learning employed by the ALS programs implementers. The modules were proposed in response to the call for instructional tools for the implementation of the PB-DALS program. The author suggested though that the materials be subjected for validation.

\section{Theme Three: On Teaching and Learning Concerns}

The implementation of various ALS programs enumerated above is not without challenges. Amongst those subjected for investigation were issues relative to the competencies of the implementers, challenges in delivering instruction in the ALS environment, logistics related concerns, and teachinglearning processes adhered to. These academic endeavors were able to point out grey areas of its implementation that necessitate immediate action by the education bureau. A study commissioned by the World Bank, for example, as regards to ALS enrollment revealed that, while enrolment registered the highest for the years 2005-2014, it likewise recorded a significant decline of A\&E passers nationwide. The body then recommended to the concerned government agencies to immediately undertake research to identify factors contributory to this issue [12].

Prior to the publication of the World Bank findings mentioned above though, results of various studies conducted about the implementation of various ALS programs already pointed out a myriad of concerns that necessitates immediate attention. Azardon and Nato's [13] meta-synthesis study on different issues about ALS, for example, tied up the A\&E takers' underperformance in the $\mathrm{A} \& \mathrm{E}$ examination to a 
problematic ALS system partly due to its usage of nonauthentic and localized assessment tools. Pinca [14] on the other hand, listed non-community-based instructional tools, delayed release of travel allowance, and lack of instructional tools while Fernandez [15] took notice of proximity of the Community Learning Centers (CLCs) to the target learners as among those that need urgent action. Finally, Abasolo [16] correlated the A\&E implementers in Talisay, Cebu City to their poor choices in teaching strategies augmented by scarcity of instructional materials such as clientele-needsbased modules to the dismal performance of the clientele in this locality to the A\&E examination.

The results of the studies conducted by Labarrete [17] though confined to a single district ALS Center in Barugo, Leyte, stressed the need to revisit the pedagogic practices adhered to by ALS implementers in the teaching of fundamental reading and study skills competencies. Results of his study revealed that A\&E learners find it rather challenging to learn the fundamentals of reading dimensions including inferencing, evaluating, and creating. Same study also revealed of a need to strengthen their study skills competence especially in outlining and semantic mapping. In addition, a separate study conducted by Labarrete [18] he suggested of a need to reengineer the teaching of writing skill in the A\&E program as the assessment result showed that the skill is still taught conventionally by its implementers. Doing so, he argued, is a novel way to address the concerns of the clientele relative to learning to write compositions of academic value. This can be done, he recommended, by enhancing the session guide for this macro language skill through the adoption of the principles contained in the constructive alignment teaching model.

Meanwhile, Labarrete [19] investigates the modalities employed by the ALS programs implementers in teaching the learners classified as Persons Deprived of Liberty (PDLs), Indigenous People, and Non-Literate Adults. Results of the findings revealed that the face-to-face is the main instructional modality employed by the ALS programs implementers across three groups. It is aided by the use of radio and modern and traditional technologies. Home visitation is also conducted. Overall, it can be categorically claimed that the manner by which instruction is delivered in the ALS is responsive in addressing learners' various needs given their circumstances. Finally, also by Labarrete [20] reported that the formats utilized in assessing students learning enrolled in the ALS-EST program include the portfolio, module-based, and performance-based. The usage of these formats, he claimed, addresses learners' diversity and conforms to the performance standards outlined in the new ALS 2.0 Curriculum.

\section{DISCUSSIONS}

Studies conducted in the ALS point to three main directions. First, on the positive impact of the program delivery to the lives of the enrollees. Based on the data presented above for this theme, it is categorical to claim that, indeed, various ALS programs in general had impacted on the lives of its takers or enrollees. These impact ranges from scholastic benefits, character formation, economic benefits, and as an opportunity to be back on school grounds and fulfill one's cherished dream of obtaining diploma and eventually a degree in college. Second, are about instructional resources developed These studies were conducted to address concerns as regards the implementation of novel program and adoption of a new curriculum which, inevitably direly need resources useful for teaching and learning. Finally, on teaching and learning concerns. These studies, generally, are focused on macro issues such competencies of the mobile teachers, challenges in teaching ALS learners, learning issues, proximity as a factor that impede learning among other things. These academic undertakings were able to uncover a number of concerns that have long since been hounding the delivery system and that needs immediate attention of the concerned authorities.

Noteworthy, is the absence of studies in Arabic Language and Islamic Values Education in ALS (ALIVE in ALS and ALS for Differently-Abled Persons (ALS-DAP). For the former, the program offering is pinned on the idea of engaging Muslim migrants as stewards of the government's peace initiatives in hope for an improved quality of life of the out-of-school youths (OSY) and adults Muslims. Its program components include Basic Literacy Program + ALIVE, Accreditation \& Equivalency (A\&E) Program + ALIVE, Informal Education + ALIVE, Technical Vocational Education Program + ALIVE, and Entrepreneurship Development + ALIVE. The latter, on the other hand, is intended for learners who require special educational needs and attention, specifically those with hearing impairment, can also study in the ALS under its program called Its instructional mode includes the usage of sign language. Children, OSY and adults denied of this privilege in the formal system are given priority [2].

Additionally, studies also on ALS program called RadioBased Instruction (RBI) are nowhere to be found. This program uses a radio as the main platform. Its goal is to expand access to education by reaching the learners where they are especially those in the remote places of the countryside. RBI aims to provide learning opportunities to listeners and use that knowledge to obtain equivalency in basic education based on the broadcasted lessons. Generally, though, it can be claimed that there is a rich data available pertinent to the studies conducted in the ALS that policy makers in this educational system can anchor with for setting direction for its research agenda.

\section{REFERENCES}

[1] Breaking down challenges in literacy | Manila Bulletin News. (2018, November 4). Retrieved.

November5,2018,fromhttps://news.mb.com.ph/2018/11/04/breakingdown-challenges-in-literacy.

[2] Department of Education. (2017). ALS Programs. Retrieved December 12,2016, from http://www.deped.gov.ph/k-to-12/inclusiveeducation/als-programs/.

[3] Apao, L., Dayagbil, F., \& Abao, E. (2014). Alternative learning system accreditation and equivalency (ALS-A\&E) program: quality of life beyond poverty. International Journal of Interdisciplinary Research and Innovations, 2(4), 20-26.

[4] Dayon, C. A., Garcines, J. V., \& Sael, M. P. (2016). Alternative Learning System Literacy Program: The Badjaos' Standpoints. International Journal of Education Research for Higher Learning,22(1), 203-220. Retrieved December 4, 2017, from https://ejournals.ph/article.php? id=13352.

[5] Flores, D. (2019). Performance of Young Mothers in the Alternative Learning System. A Research Paper Presentation from the 6th 
International and 7th National Teacher Education Students' Conference. Held on April 12 - 13, 2019 at Cebu Normal University, Cebu City, Philippines.

[6] Enriquez, L. (2013). Tracer study on passers of accreditation and equivalency program of alternative learning system in the division of Lucena City: basis for developing an intervention program. Retrieved from January 6, 2017, from https://www.academia.edu/23592577.

[7] Moralista, R., \& Delariarte G. (2014). Alternative learning system (ALS education): Its Influence on the Intellectual Abilities of Indigenous People. Asia Pacific Journal of Education, Arts, and Sciences, 1(1), 7-10.

[8] Labarrete, R. (2020). An Evaluation of the Effectiveness Of The Implementation Of Alternative Learning System Education And Skills Training (ALS-EST) Program. International Journal of Research in Education Humanities and Commerce Volume 01, No. 04; 2020.

[9] Melgar, M.C. (2019). ALS Online program for Life Skills: A Way Forward. Unpublished dissertation. Cebu Normal University, Cebu City, Philippines.

[10] Melgar, M.V. (2019). Digitization of ALS Online Program for Academic Skills: Moving On. Unpublished dissertation. Cebu Normal University. Cebu City, Philippines.

[11] Labarrete, R. (2021). A Proposed Module for The Course Modalities and Assessment of Learning in Post-Baccalaureate Diploma in Alternative Learning System (PB-DALS). Unpublished Research Article. Leyte Normal University, Tacloban City, Philippines.

[12] World Bank Report No: AUS14891. (2016, May 10). Republic of the Philippines Alternative LearningSystemStudy.RetrievedJanuary/February2017,fromhttp://doc uments.worldbank.org/curated/en/757331468297305021/pdf/AUS148 91-WP-PUBLIC-Alternative-and-Inclusive-Learning-in-thePhilippines-has-been-approved-P146307.pdf.

[13] Arzadon, C. E., \& Rogelio Jr Nato. (2015). The Philippine alternative learning system: expanding the educational future of the deprived, depressed, and undeserved. Retrieved from January 6, 2017, from https://www.academia.edu/23592577

[14] Pinca, E. (2015). The mobile teachers' profile, competencies, performance, and problems in the department of education, division of northern Samar, Philippines. International Journal of Scientific \& Technology Research, 4(12), 45-50. Retrieved January 12, 2017, from https://issuu.com/ijstr.org/docs/the-mobileteachers-profile-compete/

[15] Fernandez, R. (2013). Teachers' competence and learners' performance in the alternative learning system towards an enriched instructional program. International Journal of Information Technology and Business Management 1 (1), 33-46.

[16] Abasolo, A. Jr. (2017). Developing a Scheme of Action for Enhanced Alternative Learning System (Unpublished dissertation). Cebu Technological University, Cebu City, Philippines, 2017.

[17] Labarrete, R. A. (2019). Reading comprehension level and study skills competence of the Alternative learning system (ALS) clientele. PUPIL: International Journal of Teaching, Education and Learning, 3 (1), 220229. https://dx.doi.org/10.20319/pijtel.2019.31.220229.

[18] Labarrete, R. A. (2019). An Assessment of Alternative Learning System-Accreditation and Equivalency (ALS-A\&E) Curriculum for Secondary Clientele. CNU Journal of Higher Education, 13, 1, 43-55.

[19] Labarrete, R. (2021). Facilitating instruction in the alternative learning system (ALS). International Journal of Education Humanities and Social Science ISSN: 2582-0745 Vol. 4, No. 01; 2021.

[20] Labarrete, R. (2021). Assessment for learning in the alternative learning system- education and skills training (ALS-EST). International Journal of Education Humanities and Social Science ISSN: 2582-0745 Vol. 4, No. 01; 2021.

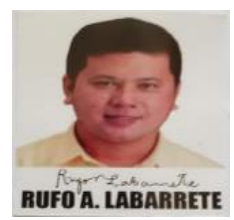

Dr. Rufo A. Labarrete is an Assistant Professor of the College of Education of the Leyte Normal University in Tacloban City, Leyte, the Philippines. He obtained his doctor of Philosophy in Education major in Curriculum and Instruction degree at the University of San Carlos in Cebu City. His research inclination is into the Alternative Learning System of the Philippines. He has attended numerous seminars and training and presented research papers in his country and abroad such as in Indonesia, Thailand, and, Japan. He has also published a number of research articles about the ALS in international refereed journals. 